\title{
International water negotiations under asymmetry, Lessons from the Rhine chlorides dispute settlement (1931-2004)
}

\section{Carel Dieperink}

Accepted: 14 July 2010/Published online: 10 August 2010

(C) The Author(s) 2010. This article is published with open access at Springerlink.com

\begin{abstract}
Negotiations concerning the quality of international rivers are not easy, as incongruence in preferences between upstream and downstream countries generally exists. The Rhine Chlorides dispute is a clear example of this. The chloride issue has been on the international water agenda of the Netherlands and the upstream Rhine riparian states for more than 70 years. The aim of this paper is to give a historical overview of the settlement of the Rhine chlorides dispute in order to draw some lessons for negotiators who have to work under comparable conditions of asymmetrical international water pollution. The case not only shows the complexities in reaching acceptable solutions for asymmetrical transboundary pollution, but also the importance of sound argumentation, institutions, side payments, issue framing, issue linking and arbitration.
\end{abstract}

Keywords Rhine - Dispute settlement - Water pollution - Water quality · Negotiations

\section{List of abbreviations}

BATNA Best alternatives to a negotiated agreement

EC European Community

ICPR International Commission for the Protection of the Rhine against Pollution

MDPA Mines Domaniales de Potasse d'Alsace (Alsatian Potassium mines)

NIMBY Not in my backyard

RIWA Rijncommissie Waterleidingbedrijven (Association of River water works)

VEWIN Vereniging van Waterbedrijven in Nederland (Association of drinking water companies in the Netherlands)

WHO World Health Organisation 


\section{Resolving incongruence in international water regime preferences}

Most of the world's major rivers are shared by two or more countries (Wolf 1997). Population and industrial growth have challenged the quality of these rivers. As a result, quality issues have arrived on the agendas of riparian states, and several states have faced the challenge of negotiating effective international regimes in order to settle disputes (Dieperink 1998, 2000; Linnerooth 1990; LeMarquand 1977; Meijerink 1999; Shmueli 1999). Such challenges are time-consuming, and generally speaking, success depends on the issues at stake and on the problem-solving capacities of the actors involved (Underdal 2001: 13-36).

The more benign an issue is, the easier it may be to find acceptable solutions. A perfectly benign problem would be one characterised by identical preferences of the states involved. Such an issue asks only for coordination of activities. The further we get from that state of harmony-the more incongruent states' preferences are, the more malign a problem is. Transfrontier pollution is an example of a more malign problem, as in cases of transfrontier pollution preferences of the upstream and downstream states tend to be asymmetrical (Dinar 2006). An upstream polluting country harvests the benefits of economic activities and suffers only a fraction of the damage at the detriment of a downstream country. Such issues will become more malign if upstream states are only interested in their own payoff and assign zero value to the welfare of other riparian states. Hegemonic stability theory suggests that non-cooperative or Rambo behaviour of upstream countries can only be avoided if downstream states can generate some reciprocal power to sway the upstream state to cooperate (LeMarquand 1977: 10; List and Rittberger 1992: 98). Cooperation is more likely if the downstream state is a hegemon (Lowi 1993; Shmueli 1999), but this is often not the case. Moreover, explanations based solely on the hegemonic variable do not take into account strategic bi-national interactions such as issue-linkage and reciprocity, offering side payments (Dinar 2006) and third party involvement, which may induce a state to cooperate. This paper focuses on the role of such interactions in settling upstream-downstream disputes.

The pollution of the Rhine by upstream chloride discharges is a classic example of an upstream-downstream conflict. The Rhine chlorides case is unique as the issue has been on the international water agenda of the Netherlands and the upstream Rhine riparian states for more than 70 years. The case shows the complexities of reaching acceptable solutions for transfrontier pollution. Despite all efforts of negotiators from the Netherlands, Germany, France and Switzerland, effective compromises could hardly be found. As a result, the chloride load (upper line in Fig. 2) and concentrations (lower line in Fig. 2) at the Dutch border continued to grow.

This article aims to give a historical overview of the settlement of the Rhine chlorides dispute in order to draw some lessons for negotiators who have to work under comparable conditions of asymmetrical international water pollution. Before drawing lessons, this article introduces the issue and analyses and discusses the negotiation processes. Five longlasting rounds of negotiations can be discerned over time. The first round of negotiations started in the early 1930s and ended with the formalisation of the interactions between the riparian states by the Convention of Bern of 1963, by which the International Commission for the Protection of the Rhine against Pollution (ICPR), an official structure for interactions, was created. In 1972, at the end of the second round of negotiations, ministers of the Rhine states took over the negotiations from their civil servants, which resulted in a proposal to settle the conflict. The 1976 Rhine Chlorides Convention formalised the compromise, but it could never be implemented due to the French refusal to ratify it. As a result of this intergovernmental impasse, Dutch private parties began legal proceedings, 
which led to a reframing of the issue for the negotiators at state level. New bargaining options were found, and the reopened negations were concluded in 1991 by a modification of the 1976 Chlorides Convention. However, an arbitral decision was needed before the issue could finally be settled. Since 2004, the issue has been off the international political agenda.

This article is based on reports and written material found in the archives of the Dutch Public Works Department and the International Rhine Commission, 20 in-depth interviews with key informants from the Rhine Commission, and an additional review of literature. Most interviews were conducted during the author's PhD research in the 1990s (Dieperink 1997).

\section{The Rhine chlorides issue}

Figure 1 shows the Rhine catchment area and its riparian states. On its 1,326 km long journey from the Alps to the North Sea, the river flows through Switzerland, France, Germany and the Netherlands, transporting the waste water of over 58 million people and an impressive number of industries (International Commission for the Protection of the Rhine 2009). Major industrial areas can be found near Basle, Mannheim and the Ruhr and Rotterdam port areas. Both communal and industrial discharges contain(ed) chlorides. The most important point source of chloride discharges used to be the Mines Domaniales de Potasse d'Alsace (MDPA), which are 24 potassium mines located northwest of Mulhouse in the Alsace, close to the German border. They mined sylvanite out of a 20,300-ha potash basin and extracted its potassium chloride content (around 27\%) to sell it, mostly as fertiliser. The rest of the material, consisting of sodium chloride $(59 \%)$ and insoluble materials (mainly clay) (14\%), had no commercial values and had to be disposed of (Schreiber and Dufond 1992, cited in Bernauer 1995). From 1910 to 1931, the MDPA had dumped the waste directly in 30-m-high piles at several sites around the mines with groundwater contamination and negative impacts on the local drinking water supply as a result (Dekker 1987, p. 3). After 1931, they constructed some small canals through which the wastes were discharged into the Rhine.

From the Dutch perspective, these discharges had negative influences on their drinking water and horticultural interests. The western half of the Netherlands is located below sea level, making it extremely vulnerable to salt seepage and invading seawaters. The artificial Lake IJssel has an important hydrological function for the country. Its fresh water is used by drinking water companies and by water boards for the flushing of the canals and lakes. Fresh Rhine water is needed to feed Lake IJssel and to construct a buffer against salt intrusions. The Netherlands draws around $65 \%$ of its fresh water supply from the Rhine.

Unacceptably, high chloride concentrations can have several undesirable effects. First, they spoil the taste of the water. Taste thresholds for the chloride anion are in the range of 200-300 mg/litre for sodium, potassium and calcium chloride (WHO 2009). Health effects of such concentrations seem to be limited, as the World Health Organisation (WHO) has not set health-based standards for chlorides. However, high chloride concentrations stimulate corrosion in the network of drinking water pipes, allowing harmful agents to leach into drinking water. Agricultural research has revealed that chloride concentrations higher than $50 \mathrm{mg} / \mathrm{l}$ could negatively influence horticulture and greenhouse vegetable production (Volker 1958: 24). Ecologically, higher concentrations in chloride, sodium and sulphate change the vegetation in a catchment as they result in a replacement of more sensitive plant species by more common species (Barendregt et al. 1992; Smolders et al. 2006). 


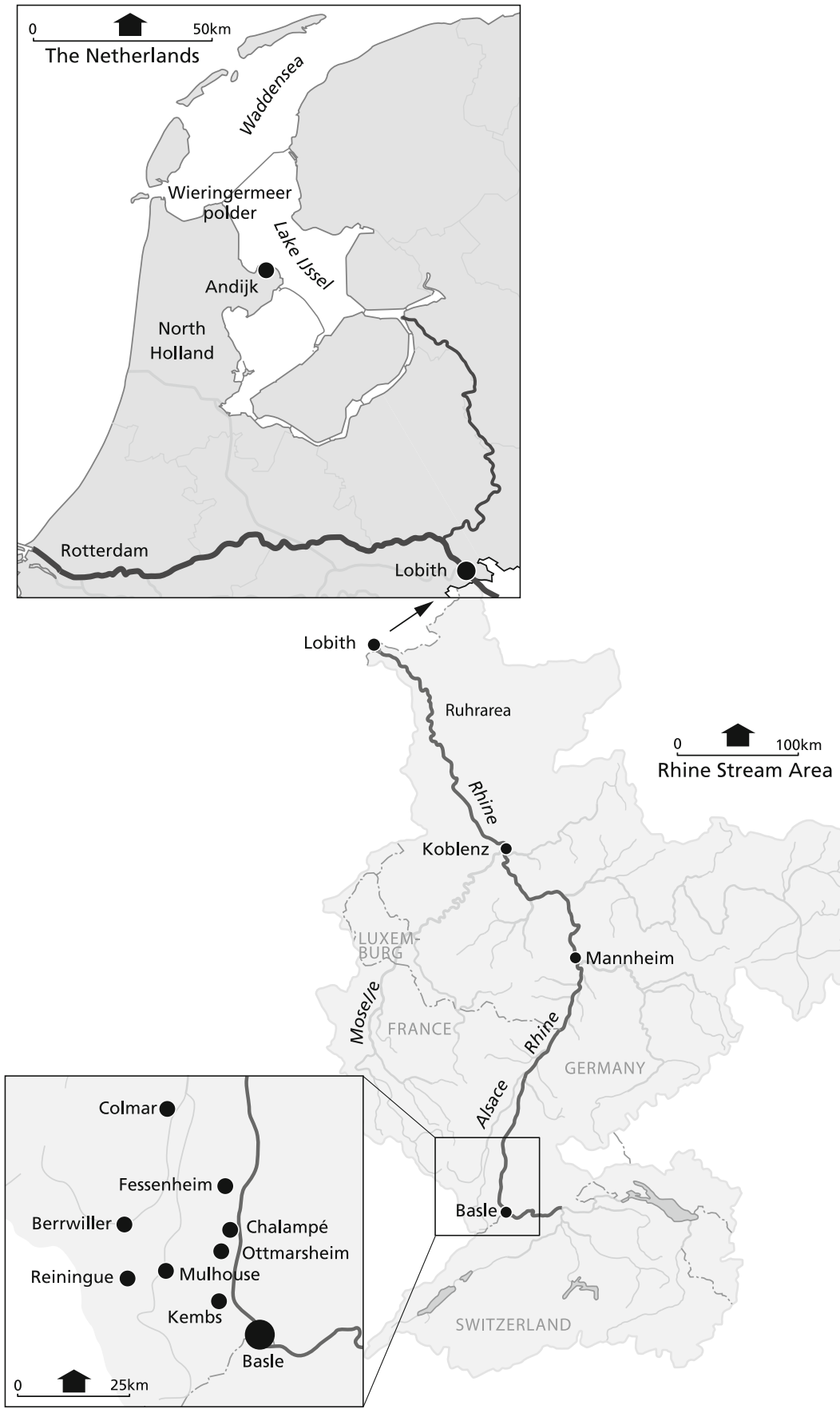

Fig. 1 The Rhine catchment area. Source Drafted for the author by the Cartographic Laboratory of the Faculty of Geosciences of Utrecht University 2010 


\section{The road to the bern convention (1931-1963)}

In the early 1930s, the chlorides issue first arrived on the Dutch agenda when two representatives of the Dutch drinking water companies accidentally discovered suspiciously large pipes at a French pipe factory, which had been bought by the Mines Domaniales de Potasse d'Alsace (MDPA) (Krul 1931). The representatives found out that the mines had got a permit to increase their production and to dump additional waste into the Rhine as the Prefect wanted to prevent a further deterioration of the groundwater. According to the licence granted, the discharges were allowed as long as the total salt concentration in the French part of the Rhine would not exceed $200 \mathrm{mg} / \mathrm{l}$. In times of low flow, wastes have to be stored in buffer basins located in Fessenheim. Calculations of the Dutch drinking water companies and the Public Works Department made it clear that the allowed discharges of the MDPA would result in an average extra chloride concentration of $52 \mathrm{mg} / \mathrm{l}$ at Lobith where the Rhine crosses the German-Dutch border (Volker 1958).

This discovery aroused Dutch fears as in those days there was an Enclosure Dike constructed specifically to transfer the Zuiderzee into the artificial fresh water Lake IJssel. Therefore, Dutch drinking water companies opted for a chloride concentration at Lobith that was as low as possible. Dutch drinking water companies were not only confronted with incoming chlorides but also with phenols that spoiled the taste and smell of the water.

Both problems induced the Public Works Department to bring the pollution of the Rhine to international attention. In 1948, delegates of the Netherlands took initiatives during a session of the Central Commission for Navigation on the Rhine, and the issues were subsequently discussed at length at an international conference concerning salmon fishing. At this conference, it was decided that an international commission of the riparian states was needed to study the pollution. This International Commission for the Protection of the Rhine against Pollution (ICPR) started its activities in 1950. Data from nine places in the catchment basin were compared and discussed, which resulted in a growing insight into the pollution of the river. More specifically, it made clear that the average chloride load at the Dutch border increased, from $180 \mathrm{~kg} / \mathrm{s}$ in 1950 to $265 \mathrm{~kg} / \mathrm{s}$ in 1960 (Fig. 2).

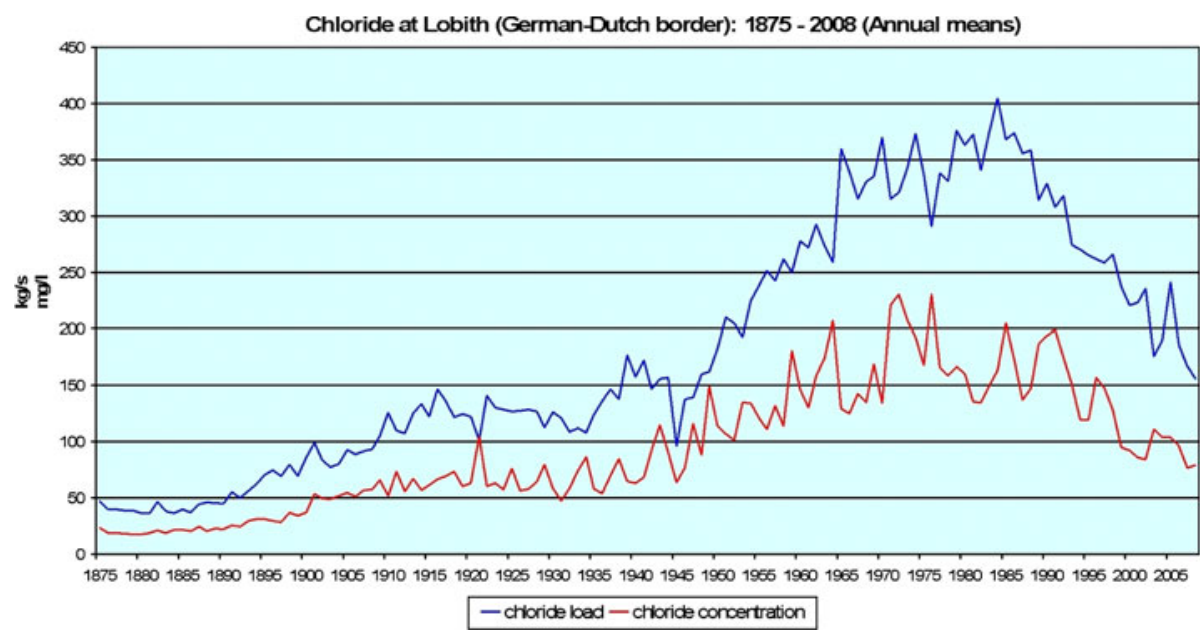

Fig. 2 Chloride loads and concentrations at the Dutch border. Source RIWA 2009 
Confronted with this increase, the Dutch opted for a freeze on the average chloride load at the 1954 level of $225 \mathrm{~kg} / \mathrm{s}$. This load would result in an average chloride concentration at the Dutch border of $125 \mathrm{mg} / \mathrm{l}$. Neither the French nor the Germans wanted to accept this freeze, as in their opinion, the problems in the Netherlands were not due to the chloride concentration in the Rhine, but a consequence of living in a low delta area with brackish groundwater. They were not convinced of the severity of the downstream situation. The Germans, who also added to the chloride load at Lobith by discharges from coalmines in the Ruhr Area, pointed out the technical impossibility of reducing the chloride concentrations of their wastewaters. Switzerland, the upstream country with hardly any chloridedischarging industries, supported the Dutch point of view. However, as both the French and the Germans refused to take immediate steps, the second-best option for the Netherlands was to initiate research to keep the problem on the agenda. The other riparian states were willing to participate in this research, and five working groups were set up in the spring of 1960 (Lammers 1974:71). While working group A was to study the effect of the salinity level of the Rhine water on agriculture, working group B was to investigate the effect of pollution on the supply of drinking water, hygiene and public health. The study of hydrological questions and water management, with particular reference to the salinity problem in the Netherlands, was assigned to working group C. Working group D was to investigate technical measures to restrict the salinity of the Rhine, while the study of economic and financial questions had to be dealt with in working group E. In 1960, research undertaken by working group $\mathrm{C}$ revealed the sources of the average load of $265 \mathrm{~kg} / \mathrm{s}$ measured at the Dutch border (International Commission for the Protection of the Rhine against Pollution 1966:12). With $85 \mathrm{~kg} / \mathrm{s}$, the Alsatian potassium mines appeared to be the major point source to be followed by discharges of $55 \mathrm{~kg} / \mathrm{s}$ of waste salts from the French and German soda industries. Another $45 \mathrm{~kg} / \mathrm{s}$ came from drainage water from coalmines in the Ruhr area, while domestic water disposal and natural salinity accounted for $80 \mathrm{~kg} / \mathrm{s}$.

During the first period of its existence, authority of the ICPR was not well defined. The participants operated on the basis of governmental memorandums, which did not hamper progress in collecting data about hydrology and pollution of the Rhine. An authority question did arise when the Dutch asked for their 1954 freeze and for measures to be taken in France concerning the waste salts of the MDPA. Germany and France argued that the ICPR lacked the authority to make recommendations to governments. In their opinion, the ICPR was only a group of experts exchanging information on water quality. Only through the insistence of the Netherlands were the other riparian states willing to concede and to prepare a draft international agreement in order to specify the future mandate of the ICPR, the basis for future negotiations. A newly formed working group, F, was put in charge of the preparations.

In 1963, Switzerland, France, Germany, the Netherlands as well as Luxembourg (riparian of the Moselle, a tributary of the Rhine) signed the Convention of Bern (Convention of Bern 1990). This Convention did not impose any substantive obligations on the riparian states but only formalised a structure for interaction (Lammers 1974: 67) as the Dutch and the Swiss could not convince France and Germany to adopt the measures necessary to reduce or eliminate the pollution. Consensus about objectives like maximum chloride loads or concentrations could not be reached. The Convention legalised existing research practice was legalised, which implied that the discussions still lacked a direction to be effective in reducing pollution. However, the Commission was given the authority to make proposals to the riparian governments on measures for protecting the Rhine against pollution and to prepare the guidelines for possible arrangements between the signatory 
Governments concerning protection of the Rhine waters. The Convention further provided that the ICPR meet in ordinary session at least once a year. During these sessions, the Commission can only take decisions unanimously although abstention from voting is permitted. During the negotiations for the Convention, the idea of establishing an independent and permanent secretariat was at first strongly opposed by France and West Germany. Especially, the French were of the opinion that a permanent secretariat would be too heavy an administrative instrument and that it would only increase the expenditure of the Commission. The Netherlands and Switzerland, however, were not prepared to continue the existing practice, which consisted of the temporary performance of secretariat activities by officials of the riparian states in addition to their regular work. A German compromise to locate the secretariat at the German Federal Institute of Hydrology in Koblenz was finally accepted. The costs of the secretariat would be divided between the riparian states according to fixed rates.

The adoption of the Convention marked the end of the first interaction round. The chlorides problem had been placed on the intergovernmental agenda through Dutch initiative using existing international organisations, by initiating (joint) research and by a successful attempt to formalise interactions. Information was generated and disseminated, but the riparian states could only reach a consensus about the sources of the chlorides pollution. Dissent existed about the Dutch complaints that the upstream chloride discharges resulted in a problem for the Netherlands. As a result, the upstream parties were not willing to freeze their discharges.

\section{Growing Ministerial involvement (1963-1972)}

Interactions continued within the now official ICPR. Some progress was made when working group D was put in charge of studying possible measures for reducing the chloride load. On the basis of its report submitted in 1963, the Commission decided to examine the feasibility of storing waste salts from the French potassium mines, the most important point source. These limitations in focus were also motivated because the MDPA salts were both undissolved and geographically concentrated in enormous quantities and therefore were comparatively easy to handle. At the request of the French delegation, an experimental stack was built in 1966 to study the hydrological behaviour and stability of a stockpile of waste salts. It appeared that the salts could be stored, provided that special measures were taken to protect the ground water. Thereafter, in May 1969, the Commission decided on a French proposal that additional technical and economic studies had to be conducted concerning the location of the stack, the transportation of the waste salts from the mines and the techniques of stacking (ICPR, International Commission for the Protection of the Rhine against Pollution 1970, p. 16). Meanwhile, it became clear that while France would agree to store the Alsatian salts, this certainly did not apply to all the salts. Only one-third to one-half of the waste could be stacked, which would reduce the discharged loads by 40-60 kg/s, respectively. Therefore, the Commission decided, again spurred by the French to look for alternative or supplementary measures to keep the salts out of the Rhine. Working groups investigated the possibility of selling the waste salts to the French sodium factories in Dombasle (120 km northwest of Mulhouse), of transporting the salts by ship to the North Sea or via a pipeline over French territory to the Channel, or of discharging part of the salts in the Doubs, a French river that originates in the Jura mountains south-west of Basle and discharges into the Saône (International Commission for the Protection of the Rhine against Pollution 1970: 14-18.). All these possibilities were rejected, however, 
mainly because of the high costs of transportation. Selling the waste chlorides to the factories in Dombasle implied that investments should be made while the soda market was very instable. Transportation by ships required enormous extra investments in eighteen pushers with 110 flat-bottomed crafts (ICPR, International Commission for the Protection of the Rhine against Pollution 1971: 18).

During negotiations in working group $\mathrm{E}$ about costs of the research, the Dutch informally dropped the polluter-pays principle and agreed to share in the cost to finance the measures that should be taken in the Alsace. From an economic point of view, offering these side payments was not irrational, as in working group A the damages suffered by the Netherlands were calculated as amounting to around 25 million Guilders (approximately 11.25 million Euro) (Volker 1992). Moreover, the financial position of the mines was said to be so weak that the mines could not pay for measures alone. France also argued that the MDPA were not the only chloride polluter of the Rhine. So the Dutch took the initiative, drafted a chlorides convention and initiated communication about this draft in working group F. The draft contained the principle of cost sharing, but the exact measures that had to be taken could still not be specified.

After narrowing down the alternatives outlined above, storage of the salts somewhere near the mines appeared to be the only feasible way of keeping the salts out of the Rhine. The additional technical and economic studies that the Commission had approved in May 1969 were completed in the summer of 1970 . Two storage sites were seriously considered: Forêt d'Hardt, an area in the vicinity of Mulhouse, and Fessenheim, a French peninsula in the Rhine. However, no agreement could be reached on either of these locations (International Commission for the Protection of the Rhine against Pollution 1971: 5). The French rejected Forêt d'Hardt because it was considered an important green area for the population of Mulhouse. The German delegation rejected storage in Fessenheim since this peninsula is situated above a border-crossing aquifer and the Germans feared further salination of the groundwater in their territory. Existing buffer basins in Fessenheim used to regulate discharges of the waste salts to prevent unacceptably high concentrations in times of low flow, were said to be leaking. From then on, the controversy over the proper location of the salt stack dominated the sessions of the Commission. In November 1971, at the plenary session held in Basle, the disagreement between the French and German delegations, as well as the insistence of the Netherlands delegation on the urgency of a solution, was explicitly noted in a resolution adopted by the Commission. The Dutch, tired of the delay, then announced that its government would take the initiative for a Conference of Ministers of the Member States of the Rhine Commission in order to reach a decision and to change French and German attitudes. Apart from the location of the stockpile, the Dutch felt that the Conference should also make decisions about the amounts of salt that had to be kept out of the Rhine and deal with the financial aspects of any measure taken for that purpose.

Dutch anger may be understandable as the chloride loads at their border changed from $273 \mathrm{~kg} / \mathrm{s}$ in 1963 to almost $350 \mathrm{~kg} / \mathrm{s}$ in 1970. In October 1971, almost all Dutch newspapers expressed outrage at the high chloride concentration and several MPs asked for more active political participation. The deterioration of the drinking water in Rotterdam also contributed to keeping the issue on the public agenda. In the spring of 1972, drinking water companies in Rotterdam and nearby Dordrecht produced such a poor tasting drinking water that inhabitants had to buy bottled water from Norway.

A conference of ministers seemed to be the only possibility for improving the quality of the Rhine. Arbitration by the International Court of Justice, as proposed by some lawyers, was considered inappropriate by the Dutch government, for the eventual outcome of such 
arbitration was not clear. Moreover, the Dutch government did not want to spoil relations with France (van Panhuys 1972). Dutch interests in expanding the agricultural budget of the European Community (EC) might have influenced this choice of strategy.

The Ministers succeeded in reaching some agreement (International Commission for the Protection of the Rhine against Pollution 1975: 10). In the first place, they decided that by 1 January 1975 at the latest, action had to begin to stack chloride ions (equivalent to an average load of $60 \mathrm{~kg} / \mathrm{s}$ ) from the potassium mines at a location unilaterally determined by France, provided that precautions were taken to protect the groundwater and the environment. The other riparian states agreed to share in financing the projected cost of 100 million French Francs (approximately 15.24 million Euro). The cost-sharing formula reflected the contributions of the countries to the pollution problem and the intensity of preferences for chloride reductions. Switzerland would contribute 6 million Francs (0.91 million Euro), France and Germany 30 million Francs (4.57 million Euro) each, and the Netherlands 34 million Francs (5.18 million Euro). Swiss and German willingness to share in the costs was made dependent on a maximum of 100 million French Francs (15.24 million Euro). Apart from this, the ministers also agreed on a freeze on other sources of chlorides, stating that a maximum chloride concentration of $200 \mathrm{mg} / \mathrm{l}$ at the Dutch border must be observed under all circumstances. The Ministers also agreed on steps to be taken to reduce other kinds of pollution. (The ICPR had to draft lists with dangerous chemical substances and set up a long-term clean-up programme). Dutch ideas to improve their position by a further change of the interaction structure were only partly accepted. Replacing the unanimity rule by a majority rule, for example, was rejected by the other riparian states. Another Dutch hope, to grant more power to the secretariat in fact-finding, was also dashed. However, the Dutch managed to get approval for the idea of periodical Ministers conferences, to which the ICPR should address its reports. A subsequent conference was planned for 1973.

By offering side payments and by lifting the issue to the ministerial level, the Dutch were able to make some progress towards the settlement of the issue. The second round of negotiations finally resulted in both a standstill agreement and an agreement on the sharing of the costs of the measures to be taken in the Alsace. Unfortunately, the latter could not completely be specified, and this would result in an open conflict between the Netherlands and France.

\section{Impasses and private law actions (1972-1981)}

Research continued to find a location to store the salts. After having studied two new sites for stacking, Berwiller/Staffelden and Kembs/Niffer, and after having reassessed the Fessenheim site, the French reported in November 1973 that none of the locations was suitable. New studies concerning new locations-Ochsengrund and Ottmarsheim-followed. The costs of stacking the salts there were estimated to be approximately five times the previously agreed on costs of FF 100 million (15.24 million Euro). Before going any further, the French ICPR delegation wanted to first settle the financial and legal aspects of storage (ICPR 1975: 13). The other riparians showed no willingness to pay additional costs, and as a result, stacking could not begin by January 1, 1975. At the 39th plenary meeting of the ICPR in September 1975, the French proposed injection into the subsoil as a new method of getting rid of the salts. As this new French proposal was cheaper than stacking the salts, the other riparian states accepted it, so it could be specified in the Rhine Chlorides Convention concluded in December 1976. According to the Convention, 
a reduction in the average annual chloride discharges of the MDPA by $60 \mathrm{~kg} / \mathrm{s}$ was to be reached in three stages (Rhine Chlorides Convention 1990).

In the first stage, the annual average chloride discharges would be reduced by an equivalent of $20 \mathrm{~kg} / \mathrm{s}$ by injecting the wastes $1,800 \mathrm{~m}$ deep into the Alsatian subsoil. To that end, an injection installation had to be built within 18 months after enforcement of the Convention. Switzerland, Germany and the Netherlands would contribute to the cost according to the 1972 cost-sharing formula. The injection could be temporarily halted if it posed a significant risk to the environment. Moreover, if the injection would cause damage and result in additional costs, the parties would consult about financial compensation. France tried to make the other riparian states fully liable for extra costs, but this was not accepted.

After consideration of the results obtained during the first stage, the French government agreed to take the necessary steps to achieve a further reduction in the chlorides load by the remaining $40 \mathrm{~kg} / \mathrm{s}$ before January 1,1980 . This could be done by injection into the subsoil or by any other means, depending on an agreement by the riparian states on technical and financial aspects. The total costs of the measures to reduce the discharges by $20 \mathrm{~kg} / \mathrm{s} \mathrm{during}$ a period of 10 years were projected at FF 132 million (approximately 20.12 million Euro) and would be shared according to the 1972 formula. In the preamble to the Convention, the aim was repeated that the concentration of chloride ions at the Dutch border would not exceed $200 \mathrm{mg} / \mathrm{l}$. The riparian states would therefore prevent any increase in the amount of chloride ions discharged into the Rhine basin in their territory. To implement this standstill obligation, all sources of chloride discharge exceeding $1 \mathrm{~kg} / \mathrm{s}$ had to be traced and controlled. Further, the ICPR was put in charge of the preparation of proposals for the further reduction in the chloride discharges over the entire course of the river within 4 years after enforcement of the Convention.

However, during the negotiations, the French Prefect of the Département Haut-Rhin had ordered the termination of the use of the porous buffer basins on the Fessenheim peninsula (Lammers 1980: 175). The Germans appeared to have made the termination of the use of these buffer basins a condition of signing the Convention. So, in times of low flow, part of the effect of the projected reduction by $20 \mathrm{~kg} / \mathrm{s}$ was already undone. Apart from this, hopes raised by the Convention soon dissipated. The Netherlands, Switzerland and Germany succeeded in having parliamentarian ratification of the Convention within 2 years. The Dutch, Germans and Swiss paid their contributions shortly after the adoption of the Convention, thus urging France to finish the construction of the technical installation for the injection quickly. The French government, however, did just the opposite. In December 1979, after long hesitation, the French government decided not to submit the Convention for approval to the Assemblée Nationale, out of fear that the Members of Parliament would refuse ratification. Environmental protection groups and local authorities in the Alsace had vigorously protested the injection of the waste salts into the subsoil, fearing that it would spoil the groundwater. Apart from this, Alsatian feelings of relative deprivation-high unemployment, landscapes spoiled by motorways and (nuclear) power plants-made the injection issue vulnerable to a "Not in my backyard or NIMBY" attitude (see also Mühlenhöver 2009). The regional actions seemed to have found enough support in the Assemblée to make the possibility of rejection of the approval real enough. In the Netherlands, reactions were furious and the highly disappointed Dutch government took the unusual step of recalling its ambassador in France "for consultation". Such a diplomatic clash had not occurred in Europe since World War II. Both the Netherlands and Germany left their lump-sum payments with the French government to underline that they were not willing to give up the matter. Switzerland, on the other hand, retrieved its payment in 1981 (Bernauer 1995: 378). 
Meanwhile three Dutch horticulturists supported by Foundation Clean Water (Stichting Reinwater), a Dutch NGO mostly consisting of lawyers, brought the chlorides case before the District Court in Rotterdam. They asked the Court to declare the discharge of waste salts by the MDPA illegal according to Dutch civil law and to direct the MDPA to compensate the horticulturists for the damage caused by the chlorides discharged. These proceedings started in 1974 and dragged on for more than 10 years.

In sum, the promising steps set during the first Rhine Ministers conference could not be put into practice during this period despite Dutch diplomatic sanctions. By refusing to take back their already paid side payments, the Dutch were only able to keep the issue on the agenda.

\section{Breaking the impasse (1981-1991)}

In an attempt to break the stalemate created by the Alsatian lobbyists, all the possible ways to get rid of the chlorides that had been researched before resurfaced in the discussion. A new option presented by the French was an internationally financed industry that would process the chlorides (ICPR 1981: 20). Setting up such an industry could have been a way out for the French government to gain acceptance for the injection proposal in the Alsace, but the other riparian states refused this option arguing that such an industry would disturb competition on the salt market. So the injection option had to remain on the agenda. An independent international research commission of 2 experts chosen by the Alsatian authorities and 2 experts proposed by the French and German government made clear that injection was possible. It revealed that injection near Reiningue was probably environmentally safer and a better option than injection near Chalampé next to German thermal sources. This research paved the way for ratification. The French Parliament ratified the Convention, which could enter into force on July 5, 1985. In that year, the average chloride load at Lobith reached its peak at $360 \mathrm{~kg} / \mathrm{s}$ (International Commission for the Protection of the Rhine against Pollution 1986: 88).

However, in February 1986, drilling at Reiningue had to be stopped due to a lack of infiltration capacity of the deeper stone layers. Injection at Chalampé had to be cancelled when furiously protesting locals occupied the site. Therefore, the French Government had to propose to the other contracting parties to dispose of the first $20 \mathrm{~kg} / \mathrm{s}$ in some other way than injection. The heads of the ICPR delegations allowed France to break the stalemate as of January 5,1987 by provisionally storing $15 \mathrm{~kg} / \mathrm{s}$ on the premises of the MDPA and by consolidating a reduction in the discharge of waste salts with $5 \mathrm{~kg} / \mathrm{s}$ resulting from the closure of a factory in Colmar in Lorraine along the French part of the Moselle.

According to the Convention, the second-stage reduction in the discharge of waste salts by withholding $40 \mathrm{~kg} / \mathrm{s}$ was to take place 2 years after the beginning of the first stage. To this end, France suggested a provisional stacking of the salts, the cost of which (FF 816,3 million, about 124.44 million Euro) had to be shared by the riparian states in accordance with the formula of the Convention. Until 1998, the MDPA would temporarily stock an equivalent of $60 \mathrm{~kg} / \mathrm{s}$ and after that date discharge the stockpiled salt into the Rhine at a rate to be agreed on. France insisted on the latter provision because it feared that it might, after 1998, find itself with the retained salt and no one to pay for its disposal (Bernauer 1995: 379).

The French proposal seemed to be the end of a long dispute, but during the Ninth Rhine Ministers Conference of October 11, 1988, the Dutch Minister of Public Works refused to agree with it. In her view, the problem of the salinity did not merit the same 
priority as before, compared to other more serious forms of chemical pollution. She preferred spending the money on the Rhine Action Programme, a new ambitious intergovernmental framework for pollution prevention and ecological recovery. This programme has broad public and political support. The prospect of spending a lot of money for only provisional stacking made the French proposal unattractive as well. Another reason for the Dutch move was that the horticultural sector had meanwhile reduced its dependence from Rhine waters using rainwater instead of surface water and also by growing less vulnerable crops. Moreover, the litigating horticulturists had obtained favourable court decisions in the Netherlands, while some Dutch drinking water companies that had gone to Court in France were said to have good prospects to obtain a favourable outcome as well.

As the Rhine Chlorides Convention also contained a standstill provision (Rhine Chlorides Convention 1990, art. 3), the Dutch did not want to abolish the whole Convention. Horticultural interests were of minor importance, but the VEWIN, the umbrella organisation of the Dutch drinking water companies was upset and reframed the issue at stake. Not only high chloride concentrations but also high sodium concentrations were put forward as drinking water problems. Non-implementation of the second and third stages of the Rhine Chlorides Convention would be problematic, especially for the Provincial Drinking Water Company of North Holland. This company had just started the construction of a water-softening installation to purify the water of its high calcium concentration. To this end, sodium had to be added. The company had based its investment on the French proposals concerning the reduction of salts (sodium chloride). Without a Convention, concentrations of chlorides and sodium in Lake IJssel (see Fig. 1) would be too high to produce drinking water meeting their standards $(150 \mathrm{mg} / \mathrm{l}$ for chlorides and $120 \mathrm{mg} / \mathrm{l}$ for sodium) (Provincie Noord-Holland, Dienst Milieu en Water, 1989). According to the VEWIN, the Dutch government had saved 100 million Guilders (approximately 45 million Euro) at the cost of the drinking water companies who had to invest an additional 300 million guilders (135 million Euro) to meet these health requirements.

Pushed by the drinking water lobby, the Dutch government reopened negotiations. Beyond the general interests of the drinking water companies concerning low salt concentrations, the interest of the Provincial Drinking Water Company of North-Holland was the main interest supported by the Dutch government. Negotiations finally resulted in a new Protocol added to the Chlorides Convention, which was accepted by the riparian states in the autumn of 1991. The compromise implied that measures would be taken in France but also in the Netherlands. The measures on French and Dutch territories would be paid for by all the riparian states according to the original cost-sharing formula. In France, salts would be temporarily stacked whenever the chloride concentration at Lobith exceeded $200 \mathrm{mg} / \mathrm{l}$ for more than $24 \mathrm{~h}$. As many salts as possible would be stacked until December 31,1998 . The maximum stacking costs to be paid by the riparian states were fixed at FF 400 million (almost 61 million Euro). For each year, a maximum cost level was specified. If the annual budget was spent, France was released from its stacking obligations. If not, the money could be used to raise the budget for the next year. After 1998, the stacks could be gradually discharged, as long as the chlorides standard of $200 \mathrm{mg} / \mathrm{l}$ at Lobith was kept and as long as the average load discharged in France did not expand. In the Netherlands, a maximum of FF 100 million (15.24 million Euro) would be invested to discharge brackish seepage water from the Wieringermeer polder to the Wadden Sea instead of Lake IJssel. This seepage from the Wieringermeer polder entered Lake IJssel just at the place where the drinking water company has its intake. Diversion would reduce the chloride concentration of Lake IJssel by about $30 \mathrm{mg} / \mathrm{l}$. 
To avoid further delays, the parties agreed to implement the modulated reductions at MDPA provisionally on the basis of a joint declaration until the 1991 agreement entered into force. The latter happened in October 1994. Germany, France and the Netherlands paid their shares as specified in the Convention. Switzerland, however, paid only half of the amount specified. The country successfully argued that by closing down a soda factory, the Swiss contribution to the chloride load had been reduced. The other riparian states accepted this reduction and valued it as a contribution of FF 12 million. The Protocol further reaffirms the standstill agreement and therefore specifies the chloride loads each riparian state discharged in 1991. The Protocol finally contains the provision that no extra measures can be taken in the catchment area to reduce salt loads.

During this period, the issue remained on the agenda as France still had to meet its treaty obligations. A creative package deal resulted as both the Dutch and the French showed greater flexibility. The Dutch reframed the issue into only a drinking water issue and could offer France more room to manoeuvre in stacking the salts. In exchange, the Dutch got side payments from France and the other riparian states for measures that better served their drinking water interests. For all riparian states, the final package deal was about 500 million FF (76, 2 million Euros) cheaper than the French proposal to store salts on a continuing basis.

\section{The final dispute concerning the auditing of accounts (1998-2004)}

According to the 1991 Protocol, France had to stack salts during the years 1991-1998. This required an initial investment of FF 40 million to be paid in 1991, while the running costs for stacking were calculated at a rate of FF 61.5 (9,37 Euro) per ton stored. The maximum running costs for each year were specified as follows (translated in Euros): 7.62 million Euro (1991), 5.79 million Euro (1992), 4.11 million Euro (1993), 11.12 million (1994), 5.48 million Euro (1995 as well as 1996) and again 7.62 million Euro (1997 and 1998). Each year, France would be released from its storage obligations once the expenditure in that year had reached the spending limit as determined. As agreed on, Germany and the Netherlands made annual advance payments to France. The Germans decided to stop paying their annual shares in 1995, when it had become clear that the quantities of chlorides actually stored remained well below the limits set out by the parties. The Dutch, afraid of the consequences of non-compliance, however, continued their payments as specified in the Protocol. As a result, France was obliged to repay to the Netherlands the surplus amounts that had been paid. No consensus could be reached on a French proposal to use the surplus to continue storage after 1998, and so France had to reimburse the money.

Disagreement arose about the calculation of the surplus to be reimbursed. According to the Netherlands, the expenditures for France were the costs of investments plus the amount of FF 61.5 (9.37 Euro) multiplied by the number of tons of chlorides stored and removed from storage. They claimed reimbursement of the sum of FF 102.33 million (15.59 million Euro) (not including interest). For France, the only purpose of the FF 61.5 amount was to calculate the spending limits during the 1991-1998 period. At the time of the final auditing, the actual costs of storage and removal from storage had to be used. France submitted that the actual costs of storage and removal from storage were about FF 167.5 or 25.52 Euro per ton, clearly much more than FF 61.5 or 9.37 Euro per ton, because of the small amounts of chlorides that were in practice stored and removed from storage. France claimed that it must only reimburse the sum of FF 55,793,779 8.50 million Euro (not including interest). 
In March 1999, during the 42nd meeting of the Coordination Committee of the Rhine Commission, the Swiss attempted to mediate between France and the Netherlands by introducing a proposal for reimbursement, which was accepted by the Germans but rejected by the Dutch. Following this, the delegations asked the (Dutch) chairman of the Rhine Commission to convince the Dutch Secretary of State of the Ministry of Public Works and Water management to take a more flexible-bargaining-position (Dekker 2009). Initially, the latter was inclined to reopen the negotiations by also taking into account chloride loads discharged in the Moselle and some extra non-foreseen costs of the Wieringermeer works not covered by the package deal. The Dutch Ministries of the Environment, of Finance and of Foreign Affairs, however, refused to reopen the negotiations. They preferred reimbursement of the Dutch money over the ongoing violation of the polluter-pays principle. The Ministry of the Environment, as well as the Ministry of Public Works and Water Management (18 million Guilders or 8.1 million Euros each) and the Ministry of Agriculture (4 million Guilders or 1.8 million Euros), had contributed to the Dutch advance payments. According to the Ministry of Foreign Affairs, the Dutch had a solid legal position. During the meeting of the International Rhine Commission in May 1999, the Dutch kept their position and asked, in accordance with the Rhine Chlorides Convention, for arbitration. France agreed and both countries nominated a former judge of the International Court of Justice as member of a tribunal that further consisted of a neutral President and a Registrar.

The tribunal gave its arbitral award at 12 March 2004 (Case concerning the auditing of accounts 2004). The tribunal decided that the calculation had to be based on the FF 61.5 figure and therefore confirmed the Dutch position. Although the French judge made the statement that the award was not in the spirit of the Chlorides Protocol, as the Netherlands would only pay $21 \%$ of the total expenditure compared with the $34 \%$ envisaged by the Protocol, France had to reimburse to the Netherlands FF 118,855,162 (18,119,353 Euros). France could only keep FF 1 million 0.15 million Euros as a compensation for cost inflation.

France immediately reimbursed the money to the Netherlands. The Dutch used the money to cover the extra investment costs of the Wieringmeer works, while the remains were divided between the Ministries of Public Works and Water Management and the Environment (each 40\%) and the Ministry of Agriculture (20\%). In order to avoid offending their French co-riparian, which they needed for future steps towards a more sustainable Rhine river catchment, the Dutch government abstained from looking for media attention. As a result, the arbitral award received minimal publicity in the Netherlands and abroad.

The final stage of the dispute was settled by arbitration. Since 1998, France has not produced any more reports about the salt storage, but the Rhine Chlorides Convention is still in force. The Dutch will inform the French if the chloride concentration at Lobith exceeds $200 \mathrm{mg} / \mathrm{l}$, but the chance that this will happen is minimal because the last Alsatian potassium mine closed in 2004 . The remaining stacks will be removed by discharging them gradually into the Rhine.

\section{Discussion}

It has taken 73 years for the chlorides issue to disappear from the Dutch international political agenda. Incongruence and an asymmetry in preferences made the issue malign despite Dutch efforts to change this. 
Conflicting opinions existed in the Netherlands on one side and France on the other. The Best Alternatives to a Negotiated Agreement (BATNA) (Fisher and Ury 1981) between the two riparian states differed. For a long time, the Dutch had a poor BATNA for they required an agreement to solve their issues. On the contrary, the French could better serve their interests without an agreement, as discharging the waste salts in the Rhine was the most attractive option for the MDPA. The mines, for long the second largest employer in the Alsace, were said to be economically marginal and unable to pay for discharge reductions. Moreover, options to reduce discharges were either met by a regional NIMBY attitude or by a co-riparian cost-based veto. While the Netherlands and France had opposing stakes in the issue, the position of Germany, however, was less clear. The German drinking water companies in the northern part of the catchment area also suffered from the chlorides discharged in France, albeit to a lesser degree compared to their Dutch colleagues, while at the same time the wastewaters of the German mines also contained chlorides. Swiss delegates could support the Dutch point of view with hardly any risk, as only a small amount of chlorides entered the Rhine from Swiss territory.

Over the years, the Dutch tried to influence the French BATNA in several ways. First, by moral appeal, based on scientific reports, that clarified the vulnerable position of their drinking water sources and horticulture. Second, by promoting changes in the riparian interaction structure. The formal institutionalisation of the ICPR with an official mandate to initiate research and to make recommendations did contribute to problem-solving capacities as it offered a platform for debate and negotiation. The Dutch have tried to speed up negotiations by organising ministerial conferences to be able to do business immediately at the highest possible political level. The Ministerial conferences received a lot of media attention, which not only put pressure on France but also required the Dutch to show the general public that the issue of the Rhine pollution was taken seriously. Media attention was especially sought when the Dutch took the unusual step to ask their ambassador to return home for consultation the moment France withdrew the proposal to inject the waste salts in the Alsatian subsoil.

In theory, issue linking and arbitration can solve international water conflicts (Mostert 1998). However, a quid pro quo strategy could not be asserted by the Dutch as for a long time, no 'exchangeable' interests could be found in other foreign affairs issues in which France would be dependent upon Dutch support. The Dutch Ministry of Foreign Affairs had made attempts, for instance during the development of the Common Agricultural Policy, but found itself in other dossiers on the same side as the French. International arbitration was not an option for the Dutch either, as they could not be sure about the outcome. In Dutch opinion, it was debatable whether a court would declare the French discharges unlawful. The latter confirms the general observation that states are reluctant to ask for third party involvement (Biswas 1999) or to resort to courts to settle water disputes (Mostert 1998; Dinar 2006). Only the issue about the accounts was settled through arbitration, mainly because since both countries were fed up with the case and desired closure of the issue.

Overall, offering of side payments appeared to be the most important strategy of the Netherlands to influence the French BATNA. The side payments changed the French BATNA and enabled the Dutch to keep the issue on the agenda. When France showed its willingness to accept side payments, it also accepted a responsibility to find a solution for the issue. The Germans were also willing to pay in order to avoid Dutch complaints and actions against German chloride discharges. For Switzerland, paying was a way to show its solidarity with its downstream riparian states. In this respect, the Rhine Chlorides case is not unique, as offering side payments appears to be a more common panacea to 
settle international river disputes. Dinar (2006: 423) shows that in 22 out of 27 treaties concerning asymmetric transboundary pollution, side payments were chosen by the downstream state as a means for solving property rights disputes.

Finally, the Dutch negotiators were able to make a strategic move due to a shift in the underlying international power structure. On the interstate level, the underlying power structure remained unchanged over time. Decision-making did and still does require a consensus among the riparian states. However, within the international system, the power structure changed the moment Dutch non-state actors achieved legal standing in France, which enabled them to take the lead in settling their case and made them less dependent on the negotiation skills of the Dutch state. This opened a policy window the Dutch and French negotiators needed to introduce new proposals that resulted in a package deal.

Compared to earlier French proposals, the 1981 package deal was a win-win situation for all riparian states. The package deal was less expensive than other options discussed before, which made it acceptable to all parties involved. The French would pay less and would discharge the waste after 1998. They could probably also use the measures to defend the position of the MDPA in new Court proceedings initiated by the Dutch drinking water companies. The Dutch would also pay less and received an improvement in their drinking water supply. In case of low flows, the mines could stack a total of $71,11 \mathrm{~kg} / \mathrm{s}$ more than the previously planned $60 \mathrm{~kg} / \mathrm{s}$. In Dutch eyes, the effect on drinking water quality of the final package deal was similar to the earlier proposals. Moreover, a large part of the Dutch payments would be spent in the Netherlands instead of flowing to a foreign polluter. Therefore, the Dutch payments would be somewhat less offending to those criticising the chloride agreements as being against the polluter-pays principle. Germany was relieved not to be confronted with Dutch demands for German chloride reductions, while the environmentally minded Swiss could continue to show their solidarity for less money. Moreover, all riparian states needed an agreement for face-saving purposes. They had invested enormous amounts of time in finding an agreement and wanted the issue off the table in order to concentrate on other Rhine-related issues that were considered more important.

The question is whether the long-lasting negotiations have resulted in more than only symbolic agreements. Without delving too much into the debate about regime effectiveness (see a.o. Young 1994; Miles et al. 2001; Underdal and Young 2004), we state that some indications for effectiveness on the outcome and impact level can be found although exclusive causal links are difficult to define.

Over time, the agreements have resulted in behavioural changes. Figure 2 shows that problems have been solved and goals have been achieved. A reduction in the average chloride concentrations occurred after 1975, which can be attributed to the standstill agreement of 1972. The same can be said about the maximum chloride concentration of $200 \mathrm{mg} / \mathrm{l}$ for Lobith, which the riparian states agreed on in the same year. Over time, the number of days on which this standard was not met has decreased. Figures of the Dutch drinking water association RIWA show that the measured maximum chloride concentrations gradually dropped from $305 \mathrm{mg} / \mathrm{l}$ in 1992 to $245.9 \mathrm{mg} / \mathrm{l}$ in 1997 and after the turn of the century further to $140 \mathrm{mg} / \mathrm{l}$ in 2002 and $111.3 \mathrm{mg} / \mathrm{l}$ in 2007 (RIWA 2009). A closer look at Fig. 2 also indicates that since 1982, the average chloride loads at the Dutch border have dropped. As only limited amounts of waste salts were stored at the MDPA (a total of 960199 ton between 1991 and 1998, which equals an average reduction of discharges by about $3.8 \mathrm{~kg} / \mathrm{s}$ ) (Case concerning the auditing of accounts, 2004, par. 134), most of the reduction in loads has to be attributed to a reduction in other point and diffuse discharges in the upper part of the catchment. The reduction in chloride discharges from other potash mines, coalmines and soda works might be a result of the 
standstill agreement. A reduction in diffuse discharges mainly occurred due to milder winters, which resulted in less salt needed for de-icing of roads (see also Bernauer 1995: 385). However, the temporary storage of waste salts did contribute to avoid the problem of unacceptably high chloride concentrations. Additionally, the Wieringermeer works have resulted in lower salt concentrations in Lake IJssel.

\section{Conclusion}

The Rhine chlorides case makes clear that malign problems resulting from incongruence in regime preferences can only be resolved if parties have the political skills to find options for exchange and to define package deals. However, the transaction costs of resolving such a problem should not be underestimated. Problem solving requires a lot of energy, especially of downstream parties that in general have poor BATNAs. The case shows that dispute settlement in an upstream-downstream context asks for a step-by-step approach. First, parties should be mutually willing to accept each other's stakes as legitimate. Downstream parties should therefore have convincing arguments based on scientific evidence and objective standards (like the WHO taste threshold of $200 \mathrm{mg} / \mathrm{l}$ ). Joint research within an international catchment organisation also contributes to mutual understanding of the position of the downstream and upstream countries. Such an international catchment organisation should also have the legal mandate to serve as a formal platform for negotiations. However, the Rhine chlorides case (as well as other cases) indicates that the chance that negotiators get results beyond the abstract or principle level is higher when they can make side payments or can offer something else in exchange. Offering side payments is of course a violation of the polluter-pays principle but, on the other hand, puts pressure on upstream countries to pay more attention to downstream interests. The history of the Rhine negotiations further highlights that going to court for international arbitration is only an option for a downstream party if it is sure that it has or can produce convincing arguments. Finally, the case also shows that activities of non-state actors can have strong impacts on the intergovernmental agendas. They may result in stalemates for international negotiations but can also introduce new opportunities for finding win-win solutions. Governmental (Inter) negotiators should have an open eye for such private initiatives.

Acknowledgments The author wishes to thank Steinar Andresen, Bob Dekker, Tom Raadgever and two anonymous reviewers for their constructive comments on earlier drafts of this paper; Fred Trappenberg for drafting the map of the Rhine catchment area; Gerrit van de Haar for providing Table 2; and Louisa de Heer for a final language check.

Open Access This article is distributed under the terms of the Creative Commons Attribution Noncommercial License which permits any noncommercial use, distribution, and reproduction in any medium, provided the original author(s) and source are credited.

\section{References}

Barendregt, A., Stam, S. M. E., \& Wassen, M. J. (1992). Restoration of fen ecosystems in the Vecht River plain: Cost-benefit analysis of hydrological alternatives. Hydrobiologia, 233, 247-258.

Bernauer, T. (1995). The international financing of environmental protection: Lessons from efforts to protect the river Rhine against chloride pollution. Environmental Politics, 4, 369-390.

Biswas, A. K. (1999). Management of international waters: Opportunities and constraints. Water Resources Development, 4, 429-441. 
Case concerning the auditing of accounts. (2004). Case concerning the auditing of accounts between the Kingdom of the Netherlands and the French Republic pursuant to the Additional Protocol of 25 September 1991 to the Convention on the Protection of the Rhine against Pollution by Chlorides of 3 December 1976, Arbitral Award of 12 March 2004, Unofficial English Translation.

Convention of Bern of 1963 (1990). In Environmental Law, International regulations Sea and Rivers, Conventions and other international regulations concerning fresh water. Milieuwetgeving, Internationale regelingen verontreiniging zee en rivieren, Verdragen en andere internationale regelgeving met betrekking tot zoet water (pp. 33-57). Zwolle: W.E.J. Tjeenk Willink.

Dekker, R. H. (1987). The international Rhine debate (Het internationale Rijnoverleg). Lelystad: RIZA, Institute for Inland Water Management and Waste Water Treatment. Unpublished paper.

Dekker, R. H. (2009). Personal communication with ir. Bob Dekker, leader of the Dutch IRC Delegation, The Hague, March, 13, 2009.

Dieperink, C. (1997). Between salt and salmon, Lessons from the development of the regime concerning Rhine pollution. Tussen zout en zalm, Lessen uit de ontwikkeling van het regime inzake de Rijnvervuiling. Amsterdam: Thesis Publishers.

Dieperink, C. (1998). From open sewer to salmon run: Lessons from the Rhine water quality regime. Water Policy, 2, 471-485.

Dieperink, C. (2000). Successes in the international cooperation in the Rhine catchment area. Physics and Chemistry of the Earth, 25, 341-347.

Dinar, S. (2006). Assessing side-payments and cost-sharing patterns in international water agreements: The geographic and economic connection. Political Geography, 4, 412-437.

Fisher, R., \& Ury, W. (1981). Getting to yes: Negotiating agreement without giving in. Boston: Houghton Mifflin.

ICPR, International Commission for the Protection of the Rhine (2009). Retreived on October, 18, 2009, from http://www.iksr.org/index.php?id=26\&L=3.

ICPR, International Commission for the Protection of the Rhine against Pollution (1966). Annual Report (Tätigkeitsbericht) 1965. Koblenz: IKSR.

ICPR, International Commission for the Protection of the Rhine against Pollution (1970). Annual Report (Tätigkeitsbericht) 1969. Koblenz: IKSR.

ICPR, International Commission for the Protection of the Rhine against Pollution (1971). Annual Report (Tätigkeitsbericht) 1970. Koblenz: IKSR.

ICPR, International Commission for the Protection of the Rhine against Pollution (1975), Annual Report (Tätigkeitsbericht) 1972-1974. Koblenz: IKSR.

ICPR, International Commission for the Protection of the Rhine against Pollution (1981), Annual Report (Tätigkeitsbericht) 1980. Koblenz: IKSR.

ICPR, International Commission for the Protection of the Rhine against Pollution (1986), Annual Report (Tätigkeitsbericht) 1985. Koblenz: IKSR.

Lammers, J. G. (1974). International cooperation for the protection of the waters of the Rhine basin against pollution. Netherlands Yearbook of International Law, 5, 59-109.

Lammers, J. G. (1980). New international legal developments concerning the pollution of the Rhine. Netherlands International Law Review, 27, 171-193.

LeMarquand, D. G. (1977). International rivers, the politics of cooperation. Vancouver: University of British Columbia Westwater Research Centre.

Linnerooth, J. (1990). The Danube River Basin: Negotiating settlements to transboundary environmental issues. Natural Resources Journal, 30, 629-660.

List, M., \& Rittberger, V. (1992). Regime theory and international environmental management. In A. Hurrell \& B. Kingsbury (Eds.), The international politics of the environment (pp. 85-109). Oxford: Oxford University Press.

Lowi, M. (1993). Water and power: The politics of a scarce resource in the Jordan River Basin. Cambridge: Cambridge University Press.

Meijerink, S. (1999). Conflict and cooperation on the scheldt river basin, a case study of decision making on International Scheldt issues between 1967 and 1997. Dordrecht: Kluwer.

Mostert, E. (1998). A framework for conflict resolution. Water International, 4, 206-215.

Mühlenhöver, E. (2009), Social Movements and the Transborder Chloride Pollution of the Rhine River, Retrieved on April 24, 2009, from http://www.developpement.durable.sciencespo.fr/publications/ cahier2.pdf.

Panhuys, H.F. van (1972). Rhine Pollution and International law (De Rijnvervuiling en het Volkenrecht). Waterschapsbelangen, 1, 3-11 and 2, 26-28.

Provincie Noord-Holland (1989). Salt concentration Wieringermeer, Diverting polder waters to the Waddensea: Fast decisionmaking neccessary (Zoutoplossing Wieringermeer, Afleiden polderwater naar 
Waddenzee: Snelle besluitvorming noodzakelijk) (Haarlem: Province of North-Holland, Department of Environment and Water).

Rhine Chlorides Convention (1990). (In Environmental Law, International regulations Sea and Rivers, Conventions and other international regulations concerning fresh water (Milieuwetgeving, Internationale regelingen verontreiniging zee en rivieren, Verdragen en andere internationale regelgeving met betrekking tot zoet water) (pp. 141-161). Zwolle: W. E. J. Tjeenk Willink.

RIWA. (2009). 30 years Rhine Water, General Parameters (30 jaar Rijnwater, Algemene Parameters), Retrieved May 1, 2009, from http://www.riwa-rijn.org/e_publikaties/162_30_jaar_waterkwaliteit.pdf.

Royen, R. P. van \& Krul, W. F. J. M. (1931). Report concerning a trip to France to study the pollution of the Rhine by the Alsatian potassium mines, presented to the Commission Taste and Smell of river waters (Rapport betreffende een reis naar Frankrijk ter nadere bestudeering van de verontreiniging van den Rijn door de Kali-mijnen in den Elzas, Uitgebracht aan de Commissie "Smaak en Reuk Rivierwater"). Amsterdam: RIWA.

Shmueli, D. F. (1999). Water quality in international rivers. Political Geography, 4, 437-476.

Smolders, A. J. P., Lamers, L. P. M., Lucassen, E. C. H. E. T., \& Roelofs, J. G. M. (2006). Internal eutrophication: how it works and what to do about it-a review. Chemistry \& Ecology, 22, 93-111.

Underdal, A. (2001). One question, two answers. In E. L. Miles, A. Underdal, A. S. Andresen, J. Wettestad, J. B. Skjaerseth, \& E. M. Carlin (Eds.), Environmental regime effectiveness, confronting theory with evidence (pp. 3-46). Cambridge Massachusetts/London: MIT Press.

Underdal, A., \& Young, O. R. (2004). Regime consequences methodological challenges and research strategies. Dordrecht: Kluwer.

Volker, A. (1958). Watermanagement of Lake IJssel related to the quality of the Rhine (Die Wasserwirtschaft des IJsselsees in Beziehung zu der Qualität des Rheinwassers) (In Rijncommissie Waterleidingbedrijven, Bericht der Zusammenkunft betreffs der Verunreinigung des Rheins (pp. 22-30). Amsterdam: RIWA.

Volker, A. (1992). Personal communication with prof. Dr. A. Volker, Pijnacker. January 22, 1992.

WHO. (2009). WHO Guidelines for drinking-water quality, third edition, incorporating first and second addenda, Retrieved October 15, 2009, from http://www.who.int/water_sanitation_health/dwq/gdwq 3rev/en/index.html.

Wolf, A. T. (1997). International water conflict resolution: Lessons from comparative analysis. International Journal of Water Resources Development, 3, 333-365.

Young, O. R. (1994). International governance, protecting the environment in a stateless society. Ithaca and London: Cornell University Press. 